\title{
PEMODELAN LAYANAN ELEKTRONIK (E-Service) PEMASARAN HASIL PERTANIAN DENGAN MENGGUNAKAN KONSEP ARSITEKTUR ENTERPRISE (Studi Kasus pada Sektor Pertanian Kabupaten Banjarnegara)
}

\author{
Muh Zia Ulkhaq \\ Sekolah Tinggi Manajemen Informatika dan Komputer Tunas Bangsa \\ Email: zia@stb.ac.id
}

\begin{abstract}
ABSTRAK
Kemajuan infrastruktur teknologi di segala bidang terutama dalam bidang pemasaran membuat perubahan cara pandang dalam melakukan transaksi penjualan. Marketplace merupakan aplikasi yang melayani jual beli dari berbagai toko dimana transaksi dapat dilakukan dari manapun dan kapan pun. Pada sektor pertanian masih banyak transaksi yang dilakukan secara tradisional, hal ini menyebabkan kurang maksimalnya informasi yang diperoleh oleh masyarakat luas dalam mengetahui ketersediaan komoditi hasil pertanian yang ada. Kurangnya informasi hasil pertanian yang ada dapat diminimalisir dengan adanya teknologi saat ini, Pembuatan model arsitektur teknologi dalam mendukung peningkatan ketersediaan informasi hasil komoditas di susun berdasarkan konsep arsitektur enterprise terdiri dari arsitektur bisnis, arsitektur data, arsitektur aplikasi dan arsitektur teknologi. Proses validasi model dilakukan dalam tiga tahapan dengan menggunkan prototype aplikasi. Hasil validasi terhadap model telah terpenuhi dengan menghasilkan lima evaluasi terhadap model layanan, yaitu transaksi langsung dengan melihat hasil komoditas, jaminan terhadap komoditas yang di perjual belikan, adanya penambahan jumlah komoditas dan data petani harus sudah terdaftar dalam Dinas Pertanian serta minimal jumlah pembelian.
\end{abstract}

Kata Kunci : Informasi Hasil Pertanian, Arsitektur Enterprise,Prototype Aplikasi

\section{Pendahuluan}

Banyaknya data hasil komoditas pertanian di Indonesia dapat diperoleh dari beberapa sumber website penyedia informasi komoditas yang dimiliki oleh pemerintah seperti pertanian.go.id milik kementrian pertanian, data.go.id, bps.go.id ataupun website Pemerintah Kabupaten masingmasing daerah di Indonesia. Banyaknya data yang ada tidak serta merta diimbangi dengan update informasi terkini dari ketersediaan komoditas yang ada. Hal ini menyebabkan informasi ketersediaan komoditas menjadi kurang dapat dimanfaatkan secara maksimal.

Beberapa website penyedia infomasi ketersediaan komoditas memang memberikan data yang banyak dari tahun ke tahun, tetapi terkait ketersediaan komoditas terbaru masih belum dapat disediakan secara maksimal. Hal ini dapat dilihat dari beberapa situs penyedia informasi ketersedian komoditas yang dimiliki oleh Pemerintah seperti pertanian.go.id dimana data terbaru yang di publikasikan masih tahun 2014 Pertanian.go.id (2017), sedangkan untuk data dari bps.go.id terkait luas panen padi menurut provinsi dapat dilihat bahwa update terkhir adalah tahun 2016 dan yang berisi data terbaru masih berupa data tahun 2015 Bps.go.id (2016), hal ini tentunya menyebabkan ketersediaan informasi komoditas yang ada belum dapat di maksimalkan secara baik.
Berdasarkan data yang di publikasikan oleh Pemkab. Banjarnegara dimana data terakhir adalah tahun 2012 maka sangat diperlukan adanya ketersediaan informasi komoditas yang up to date dalam memberikan informasi ketersediaan komoditas pertanian kepada masyarakat luas. Untuk membuat sebuah model layanan elektronik informasi pertanian dibutuhkan konsep dari arsitektur enterprise dimana arsitektur enterprise sendiri merupakan kumpulan prinsip, metode dan model yang bersifat masuk akal yang digunakan untuk mendesain dan merealisasikan sebuah struktur organisasi enterprise, proses bisnis, sistem informasi dan infrastrukturnya seperti penelitian yang dilakukan oleh Sani et al. (2015). Karakteristik utama sebuah arsitektur enterprise adalah kemampuan dalam menyediakan cara pandang yang menyeluruh tentang sebuah enterprise.

Kurangnya informasi hasil pertanian yang ada dapat diminimalisir dengan adanya teknologi saat ini. Maraknya perkembangan gadget maupun komputer serta dukungan akses internet yang semakin baik dapat digunakan sebagai alat bantu dalam mengatasi permasalah yang ada serta dukungan pengguna internet di Indonesia yang sudah mencapai 34,9\% Berliyanto (2015). Dengan adanya layanan elektronik informasi hasil pertanian desa diharapkan dapat membantu masyarakat dalam mendapatkan informasi terkait 
hasil komoditas yang ada, baik komoditas siap panen (komoditas yang masih dalam masa tanam), komoditas siap jual ataupun harga terbaru dari komoditas yang ada.

Kabupaten Banjarnegara merupakan kota yang penduduknya mayoritas berpencaharian sebagai petani, Penduduk Banjarnegara yang mencapai satu juta lebih, sebagian besar atau 623.000 jiwa dengan luas wilayah 106.971 hektar. Dengan lahan pertanian sawah seluas 14.663 hektar dan lahan pertanian bukan sawah yang terdiri dari tegalan $44.478 \mathrm{Ha}$, perkebunan 3223 Ha dan kolam seluas 519 Ha. Dengan potensi yang ada tersebut sangat relevan jika Banjarnegara sangat mengandalkan bidang pertanian sebagai potensi utama di Banjarnegara Banjaregarakab.go.id (2012).

Penelitian ini mengambil sampel data pada Kab. Banjarnegara, dimana Banjarnegara merupakan kota yang penduduknya mayoritas berpencaharian sebagai petani. Kebijakan pemerintah yang di buat oleh Menteri Pertanian Sulaiman (2015), terkait strategi pembangunan pertanian 2015-2019 yang dituangkan dalam Peraturan Menteri Pertanian Republik Indonesia Nomor 19/Permentan/HK.140/4/2015 yang diantaranya berkaitan dengan kebijakan peningkatan daya saing produk pertanian melalui standarisasi produk dan proses peningkatan rantai pasok, mutu dan keamanan pangan serta penggunaan teknologi dalam pengembangan berkelanjutan.

Untuk membuat sebuah model layanan elektronik informasi pertanian dibutuhkan konsep dari arsitektur enterprise dimana arsitektur enterprise sendiri merupakan kumpulan prinsip, metode dan model yang bersifat masuk akal yang digunakan untuk mendesain dan merealisasikan sebuah struktur organisasi enterprise, proses bisnis, sistem informasi dan infrastrukturnya Sani et al. (2015), karakteristik utama sebuah arsitektur enterprise adalah kemampuan dalam menyediakan cara pandang yang menyeluruh tentang sebuah enterprise.

\section{Metodologi Penelitian}

Pada penelitian ini metodologi yang digunakan menggunakan penelitian desain dimana menurut Hevner et al. (2004), memberikan tujuh petunjuk dalam melakukan penelitian:

Dalam menentukan model akan dilakukan analisa terhadap permasalahan yang ada, dengan melakukan analisa terhadap permasalahan yang dihadapi, tantangan serta kebutuhan dari model layanan elektronik yang akan dibuat. Dalam membuat model akan menggunakan prinsip arsitektur enterprise diantaranya:

\section{- Bisnis}

Dalam menentukan model layanan elektronik dimulai dengan mempertimbangkan manfaat model dari segi bisnis, bagaimana model yang akan dibuat haruslah mampu untuk merepresentasikan dan memberikan solusi permasalahan yang ada sehingga model yang dihasilkan benar-bernar sesuai dengan tujuan utama dari penelitian ini.

- Data

Model yang dihasilkan haruslah memiliki data yang benar - benar akurat, data yang akan dihasilkan harus diperhatikan bagaimana proses pengumpulanya sampai dapat diolah menjadi informasi yang akurat.

- Aplikasi

Pada tahapan ini akan mempertimbangkan dari segi aplikasi (kemudahan akses, kemudahan pengelolaan data dan keamanan aplikasi)

- Teknologi

Pada tahapan selanjutnya adalah menyelaraskan aplikasi yang dibuat dengan infrastruktur teknolgi yang ada saat ini, model yang akan dihasilkan haruslah mampu mengakomodir teknologi yang ada sehingga tidak terjadi kesenjangan antara model yang dibuat dengan teknologi yang ada sehingga menyebabkan kurang berhasilnya model yang dihasilkan Solusi berbasis teknologi yang relevan untuk masalah bisnis.

Dalam penelitian ini untuk menentukan solusi dari permasalahan yang selain dengan membuat model layanan elektronik penelitian ini juga akan membuat sebuah prototype aplikasi dalam mengimplementasikan layanan elektronik informasi layanan pertanian desa. Dalam membuat prototype akan merujuk pada konsep arsitektur enterprise.

1. Adanya Evaluasi

Pada tahapan ini akan mengevaluasi aplikasi yang akan diimplementasikan, evaluasi akan dilakukan sampai dihasilkan model dan prototype aplikasi yang merepresentasikan kebutuhan yang ada saat ini.

2. Kontribusi penelitian

Pada tahapan ini, kontribusi yang diberikan berupa model layanan elektronik yang digunakan untuk pengembangan penelitian kualitatif. 
3. Pengembangan aplikasi berdasarkan model layanan elektronik.

Aplikasi yang akan dibuat berdasarkan kebutuhan dari model layanan elektronik dengan mempertimbangakan temuan dilapangan serta kebutuhan dari penyedia informasi dan penerima informasi.

Prototype sebagai bagian dalam kemudahan dalam implementasi layanan elektronik

Adanya presentasikan secara efektif baik kepada audien yang berorientasi pada teknologi dan managemen

Pada tahapan ini akan dilakukan studi kelayakan dari model yang sudah dibuat dengan dipresentasikan kepada audien (kelompok tani).

\section{Metodologi Pengumpulan Data \\ Observasi}

Observasi menurut Purnomo (2008), adalah proses pengamatan dan pencatatan secara sistematis mengenai gejala-gejala yang diteliti. Observasi ini menjadi salah satu dari teknik pengumpulan data apabila sesuai dengan tujuan penelitian, yang direncanakan dan dicatat secara sistematis, serta dapat dikontrol keandalan (reliabilitas) dan kesahihannya (validitasnya). Dalam penelitian ini observasi dilakukan dengan mengamati langsung kepada kelompok tani untuk mengetahui fenomena yang terjadi dilapangan, kebutuhan, tantangan, permasalahan dan memberikan solusi terhadap permasalahan yang ada. Observasi dilakukan langsung kepada kelompok tani karena kelompok tani merupakan kumpulan petani/ peternak/ pekebun yang dibentuk atas dasar kesamaan kepentingan, kesamaan kondisi lingkungan (sosial, ekonomi, sumber daya) dan keakraban untuk meningkatkan serta mengembangkan usaha anggota hal ini sesuai dengan peraturan Menteri Pertanian Nomor: 73/Kpts/OT.160/4/2007 yang di buat oleh Apriyantono (2007).

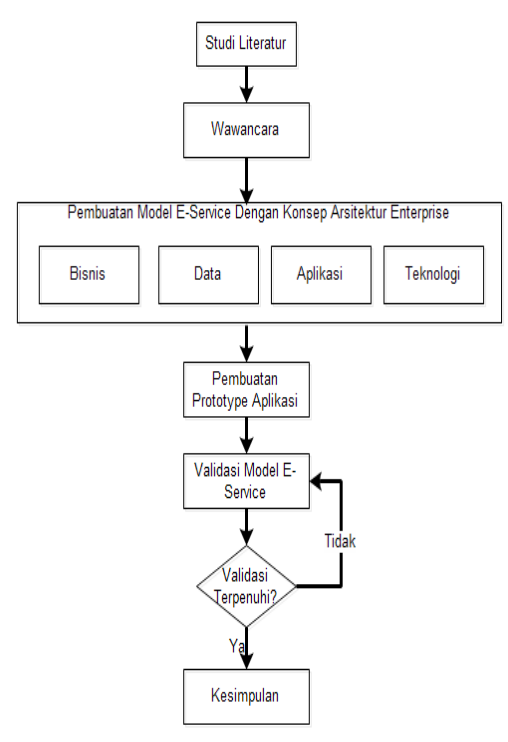

Gambar 1. Tahapan Penelitian

\section{Hasil dan Pembahasan}

Fokus pada penelitian ini adalah bagaimana membuat model layanan elektronik hasil potensi pertanian, mulai dari proses pengumpulan data dilapangan, pembuatan model E-Service dengan menggunakan konsep arsitektur enterprise yang terdiri dari arsitektur bisnis, arsitektur data, arsitektur aplikasi dan arsitektur teknologi serta bentuk prorotype sebagai validasi model layanan elektronik.

Berdasarkan hasil pengumpulan data yang dilakukan terhadap kelompok tani, pedagang dan konsumen, maka dirumuskan empat komponen utama yang digunakan dalam mendukung pembuatan model E-Service seperti informasi ketersediaan hasil komoditas pertanian, proses transaksi penjualan dan pembelian komoditas, informasi harga komoditas dan harapan kedepan terkait komoditas pertanian beras.

\section{a. Model Arsitektur Enterprise E-Service}

Pada tahapan ini akan ditentukan kebutuhan dari model layanan E-Service yang dibuat berdasarkan analisa kebutuhan yang sudah dilakukan pada tahapan sebelumnya. Pada tahapan ini pembuatan model akan dipresentasikan menggunakan konsep arsitektur enterprise yang mempertimbangkan dari arsitektur bisnis, arsitektur data, arsitektur aplikasi dan arsitektur teknologi Sani et al. (2015), Pembuatan model $E$ Service berdasarkan hasil analisa yang ditemukan dilapangan maka dihasilkan arsitektur enterprise seperti terlihat pada tabel 5.1, 5.2, 5.3, 5.4, dan 5.5 di bawah ini. 
Tabel 1 Arsitektur Bisnis

\begin{tabular}{|c|c|c|}
\hline No & Arsitektur Bisnis & $\begin{array}{c}\text { Keterlibatan } \\
\text { Aktor }\end{array}$ \\
\hline 1 & $\begin{array}{c}\text { Proses penyampaian } \\
\text { informasi ketersediaan } \\
\text { komoditas siap panen }\end{array}$ & $\begin{array}{c}\text { Petani } \\
\text { Kelompok Tani } \\
\text { Pedagang } \\
\text { Konsumen } \\
\text { Dinas Pertanian }\end{array}$ \\
\hline 2 & $\begin{array}{c}\text { Proses penyampaian } \\
\text { informasi ketersediaan } \\
\text { komoditas siap jual }\end{array}$ & $\begin{array}{c}\text { Petani } \\
\text { Pedagang } \\
\text { Konsumen } \\
\text { Dinas Pertanian }\end{array}$ \\
\hline 3 & $\begin{array}{c}\text { Proses transaksi } \\
\text { penjualan dan } \\
\text { pembelian komoditas }\end{array}$ & $\begin{array}{c}\text { Petani } \\
\text { Pedagang } \\
\text { Konsumen }\end{array}$ \\
\hline 4 & $\begin{array}{c}\text { Proses penyampaian } \\
\text { informasi konteks } \\
\text { kepemilikan }\end{array}$ & Petani \\
\hline
\end{tabular}

Tabel 2 Arsitektur Data

\begin{tabular}{|c|c|c|}
\hline No & Jenis Data & Keterangan \\
\hline 1 & $\begin{array}{l}\text { Jenis } \\
\text { Komoditas }\end{array}$ & $\begin{array}{l}\text { Berisi data jenis dari } \\
\text { komoditas siap panen } \\
\text { dan siap jual }\end{array}$ \\
\hline 2 & $\begin{array}{l}\text { Jumlah } \\
\text { Komoditas }\end{array}$ & $\begin{array}{l}\text { Berisi data banyaknya } \\
\text { jumlah komoditas siap } \\
\text { jual }\end{array}$ \\
\hline 3 & Luas Lahan & $\begin{array}{lr}\text { Berisi data luas lahan } \\
\text { yang } & \text { ditanami } \\
\text { komoditas } & \end{array}$ \\
\hline 4 & Lokasi & $\begin{array}{l}\text { Berisi data daerah } \\
\text { penghasil komoditas }\end{array}$ \\
\hline 5 & $\begin{array}{l}\text { Kualitas } \\
\text { Komoditas }\end{array}$ & $\begin{array}{l}\text { Berisi data kualitas dari } \\
\text { komoditas komoditas } \\
\text { siap jual }\end{array}$ \\
\hline 6 & $\begin{array}{l}\text { Pemilik } \\
\text { Komoditas }\end{array}$ & $\begin{array}{l}\text { Berisi data pemilik dari } \\
\text { komoditas }\end{array}$ \\
\hline 7 & $\begin{array}{l}\text { Harga } \\
\text { Komoditas }\end{array}$ & $\begin{array}{l}\text { Berisi data harga dari } \\
\text { komoditas }\end{array}$ \\
\hline 8 & Konsumen & $\begin{array}{l}\text { Berisi data konsumen } \\
\text { pembeli komoditas }\end{array}$ \\
\hline 9 & $\begin{array}{l}\text { Jumlah } \\
\text { Pembelian }\end{array}$ & $\begin{array}{ll}\text { Berisi data } & \text { banyaknya } \\
\text { jumlah } & \text { pembelian } \\
\text { komoditas } & \end{array}$ \\
\hline 10 & Pemesanan & $\begin{array}{l}\text { Berisi data pemesanan } \\
\text { komoditas siap panen }\end{array}$ \\
\hline 11 & Pembayaran & $\begin{array}{l}\text { Berisi data pembayaran } \\
\text { komoditas }\end{array}$ \\
\hline 12 & Penawaran & $\begin{array}{l}\text { Berisi data penawaran } \\
\text { komoditas siap panen }\end{array}$ \\
\hline
\end{tabular}

Tabel 3 Ringksan Arsitektur Aplikasi

\begin{tabular}{|c|c|c|}
\hline No & $\begin{array}{l}\text { Arsitektur } \\
\text { aplikasi }\end{array}$ & Keterangan \\
\hline 1 & $\begin{array}{l}\text { Modul data } \\
\text { komoditas siap } \\
\text { panen }\end{array}$ & $\begin{array}{c}\text { Berfungsi untuk } \\
\text { mengakomodir data } \\
\text { komoditas siap panen } \\
\text { (komoditas yang maasih } \\
\text { berda dalam masa } \\
\text { tanam) }\end{array}$ \\
\hline 2 & $\begin{array}{l}\text { Modul data } \\
\text { komoditas siap } \\
\text { jual }\end{array}$ & $\begin{array}{c}\text { Berfungsi untuk } \\
\text { mengaomodir data } \\
\text { komoditas siap jual } \\
\text { (data komoditas yang } \\
\text { sudah terpanen) }\end{array}$ \\
\hline 3 & $\begin{array}{l}\text { Modul profil } \\
\text { pengguna }\end{array}$ & $\begin{array}{c}\text { Berfungsi untuk } \\
\text { mengakomodir profil } \\
\text { dari pengguna dalam hal } \\
\text { ini konsumen pembeli } \\
\text { komoditas }\end{array}$ \\
\hline 4 & Modul transaksi & $\begin{array}{c}\text { Berfungsi untuk } \\
\text { megakomodir seluruh } \\
\text { transaksi penjualan dan } \\
\text { pembelian komoditas }\end{array}$ \\
\hline 5 & Modul notifikasi & $\begin{array}{l}\text { Berfungsi untuk } \\
\text { mengakomodir adanya } \\
\text { pemberitahuan } \\
\text { pemesanan ataupun } \\
\text { penawaran komoditas }\end{array}$ \\
\hline 6 & $\begin{array}{l}\text { Modul profil } \\
\text { pemilik } \\
\text { komoditas } \\
\end{array}$ & $\begin{array}{c}\text { Berfungsi untuk } \\
\text { mengakomodir profil } \\
\text { dari pemilik komoditas }\end{array}$ \\
\hline
\end{tabular}

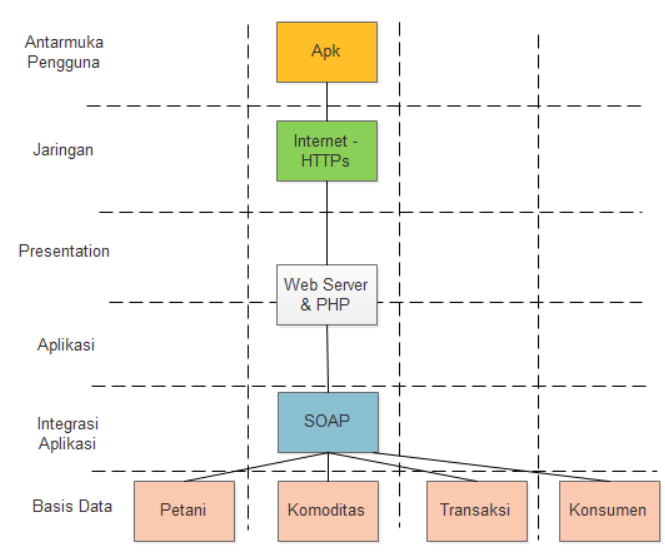

Gambar 2 Arsitektur Teknologi

Antarmuka dalam arsitektur teknologi EService menggunakan APK (Aplication Package File) yang merupakan format berkas untuk mendistribusikan dan memasang software serta middleware ke ponsel dengan sistem operasi android. Jaringan yang digunakan dalam arsitektur 
teknologi menggunakan internet-HTTPs (Hypertext Transfer Protocol Securre) untuk mengantisipasi terjadinya error program sebuah data dan kerusakan Server akibat kegagalan koneksi.

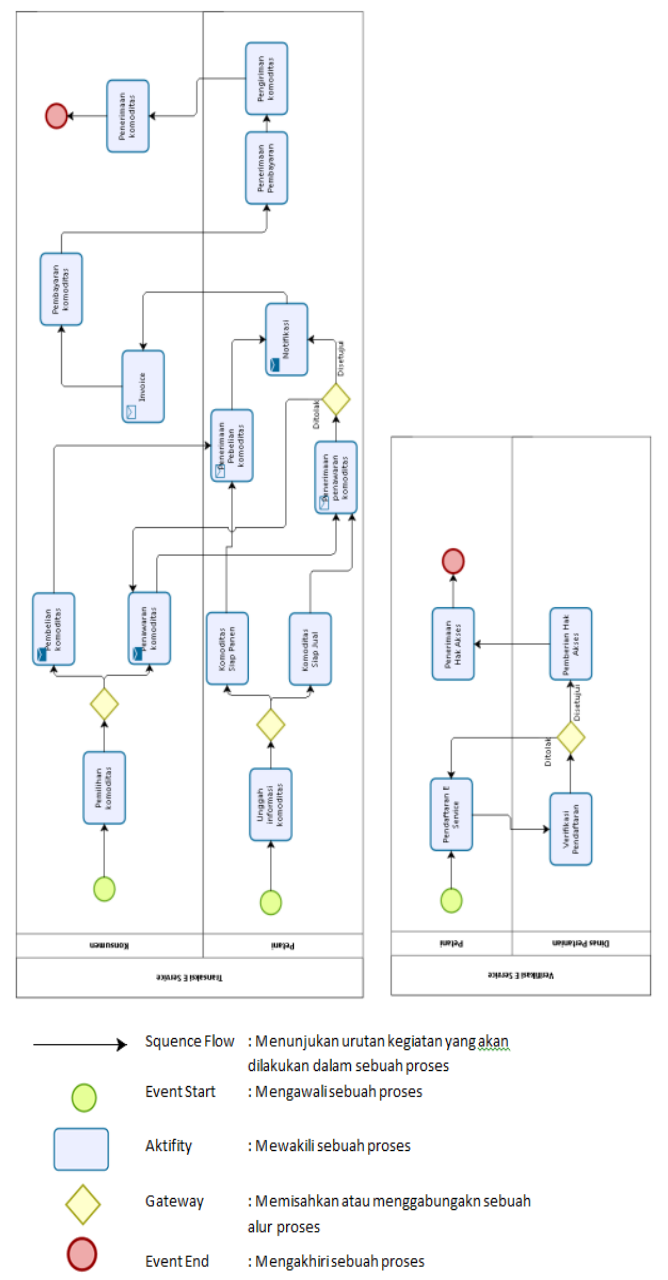

\section{Gambar 3. Model E-Service Informasi Potensi Pertanian Desa}

Gambar diatas merupakan model layanan elektrronik (E-Service) hasil dari penggunaan arsitektur enterprise. Setelah model E-Service dihasilkan kemudian dilakukan proses validasi model dengan menggunakan prototype aplikasi e service.

\section{Validasi model E-Service}

Validasi dilakukan oleh petani, kelompok tani, konsumen dan Dinas Pertanian. Pada tahapan ini proses validasi dilakukan dengan pengecekan fitur-fiur yang ada di dalam prototype aplikasi untuk kemudian disesuaikan dengan model EService.

Pengecekan fitur-fitur yang ada berfokus pada arsitektur data, arsitektur bisnis dan arsitektur aplikasi. Proses validasi yang dilakukan dalam penelitian ini sebanyak tiga tahapan dengan melibatkan konsumen, pedagang, petani dan Dinas pertanian.

Pada validasi tahapan yang pertama ada beberapa masukan yang diperoleh diantaranya adalah tampilan dari prototype yang masih kurang menarik dan ada beberapa fitur yang belum dapat memberikan ketersediaan informasi penawaran, luas lahan, jumlah komoditas dan pembayaran komoditas. Tampilan prototype aplikasi pada validasi tahapan pertama seperti terlihat pada Gambar 5.3:

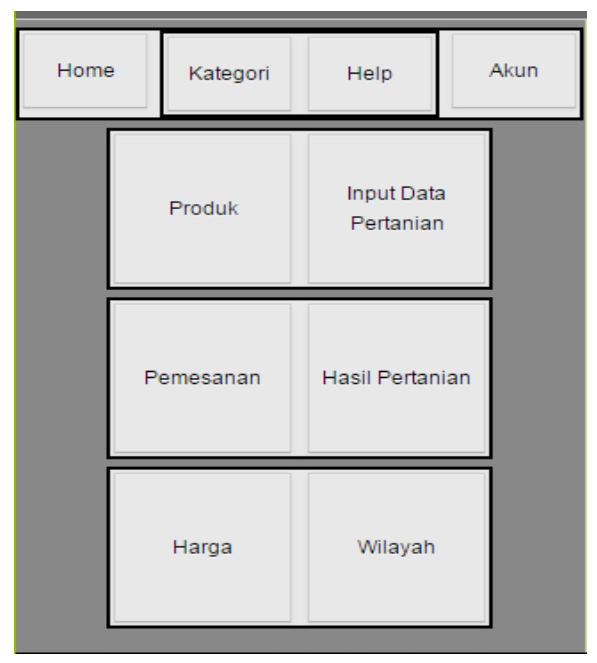

\section{Gambar 4. Protoype aplikasi validasi tahap pertama}

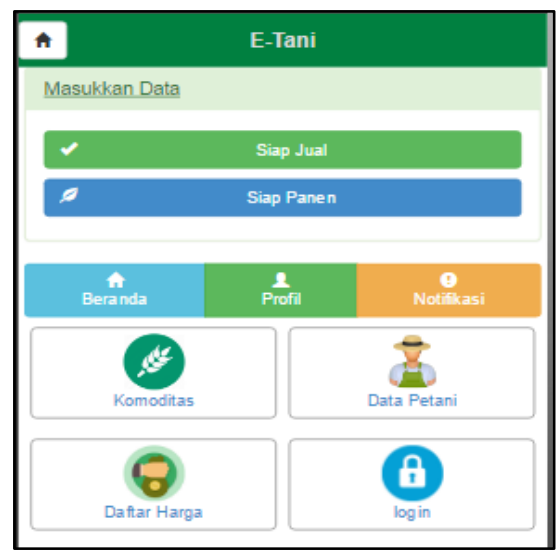

\section{Gambar 5. Prototype Aplikasi validasi tahap kedua}

Validasi tahap kedua melibatkan empat konsumen, dua petani dan dua pedagang. Sama dengan proses validasi yang dilakukan pada tahapan yang pertama, fokus kepada pengecekan 
fitur-fitur yang ada didalam prototype E-Service dengan fokus utama adalah pengecekan fitur-fitur yang pada validasi tahapan pertama masih terdapat kekurangan. Pada validasi tahapan kedua untuk kekurangan pada validasi tahapan pertama sudah terpenuhi.

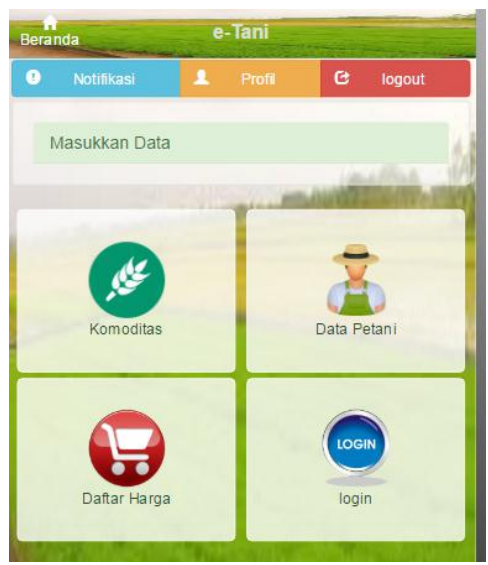

\section{Gambar 6. Prototype Aplikasi validasi tahap ketiga}

validasi tahapan yang ketiga fokus utama adalah penambahan aktor dalam memvalidasi prototype E-Service untuk menambah kevalidan dari proses validasi prototype E-Service terhadapa model E-Service. Pada validasi tahapan yang ketiga selain melibatkan lima konsumen, tiga pedagang dan dua petani juga terdapat Dinas Pertanian sebagai pemvalidasi prototype EService

Proses validasi berfokus kepada pengecekan fitur-fitur yang ada di dalam prototype aplikasi apakah sudah sesuai dengan kebutuhan ketersediaan model layanan E-Service. secara keseluruhan dari proses validasi yang sudah dilakukan sudah memenuhi apa yang ada di dalam model layanan E-Service

\section{Kesimpulan}

Dari penelitian yang sudah peneliti lakukan, maka dapat diambil kesimpulan bahwa model layanan elektronik (E-Service) terdiri dari arsitektur bisnis yang didukung dengan adanya arsitektur data kemudian dilengkapi dengan arsitektur aplikasi untuk mendukung kelengkapan dari arsitektur enterprise adapun arsitektur teknologi dibuat menyesuaikan teknologi yang ada saat ini. Dalam pembuatan konsep arsitektur enterprise dibuat berdasarkan kebutuhan data yang didapatkan dalam penelitian ini.

Dari model yang ada kemudian dibuat prototype aplikasi dalam platform Android yang digunakan untuk memvalidasi model E-Service untuk melihat sejauh mana kesesuaian ketersediaan informasi yang ada didalam model E-Service dengan prototype aplikasi E-Service

Dari hasil evaluasi secara keseluruhan, didapatkan lima evaluasi terhadap model layanan E-Service yaitu transaksi langsung dengan melihat hasil komoditas, jaminan terhadap komoditas yang di perjual belikan, adanya penambahan jumlah komoditas dan data petani harus sudah terdaftar dalam Dinas Pertanian serta minimal jumlah pembelian.

\section{Daftar Pustaka}

[1] Apriyantono, A. (2007). Peraturan Menteri Pertanian Nomor: 273/Kpts/OT.160/4/2007.

[2] B, H. K. ., C, G. A. ., D.d, K., B.a, T., van der Merwe A.b, R.e, W.,... Woitsch, R. (2015). A new paradigm for the continuous alignment of business and IT: Combining enterprise architecture modelling and enterprise ontology. Computers in Industry, -. http://doi.org/10.1016/j.compind.2015.07. 009

[3] Berliyanto. (2015). Profil Pengguna Internet di Indonesia Tahun 2015. Retrieved April 15, 2016, from http://blog.idkeyword.com/profilpengguna-internet-di-indonesia-tahun2015/

[4] Geografi Indonesia. (2016). Retrieved April 10, 2016, from http://www.indonesia.go.id/in/sekilasindonesia/geografi-indonesia

[5] Hevner, A. R., March, S. T., Park, J.,

[6] \& Ram, S. (2004). Design Science in Information Systems Research, 28(1), 75105. http://doi.org/10.2307/25148625

[7] Islam, M. S. (2011). Adoption of mobile phones among the farmers: A case study from rural Bangladesh, 2011, 1-20. Retrieved from http://oru.divaportal.org/smash/record.jsf?pid=diva2:44 0085

[8] Islam, M. S., \& Grönlund, A. (2010). Agriculture market information services (AMIS) in the least developed countries (LDCs): Nature, scopes, and challenges. Lecture Notes in Computer Science (Including Subseries Lecture Notes in Artificial Intelligence and Lecture Notes 
in Bioinformatics), 6228 LNCS, 109-120. http://doi.org/10.1007/978-3-642-147999_10

[9] M. Sirajul Islam, A. G. (2007). Agriculture Market Informatioan EService in Bangladesh: A StakeholderOriented Case Analysis, 9248(April 2016), 258-269. http://doi.org/10.1007/978-3-319-22479-4

[10] Manson, S. M., Jordan, N. R., Nelson, K. C., \& Brummel, R. F. (2016). Modeling the effect of social networks on adoption of multifunctional agriculture. Environmental Modelling and Software, 75, 388-401. http://doi.org/10.1016/j.envsoft.2014.09.0 15

[11] Mwongera, C., Shikuku, K. M., Twyman, J., Läderach, P., Ampaire, E., Asten, P. Van, ... Winowiecki, L. A. (2016). Climate smart agriculture rapid appraisal ( CSA-RA ): A tool for prioritizing contextspeci fi c climate smart agriculture technologies. Agsy. http://doi.org/10.1016/j.agsy.2016.05.009

[12] Navarro, J., Bryan, B. A., Marinoni, O., Eady, S., \& Halog, A. (2016). Mapping agriculture's impact by combining farm management handbooks, life-cycle assessment and search engine science. Environmental Modelling and Software, 80, 54-65. http://doi.org/10.1016/j.envsoft.2016.02.0 20

[13] Ntaliani, M., Costopoulou, C., Karetsos, S., Tambouris, E., \& Tarabanis, K. (2010). Agricultural e-government services: An implementation framework and case study. Computers and Electronics in Agriculture, 70(2), 337347.

http://doi.org/10.1016/j.compag.2009.09.0 08

[14] Purnomo, H. U. dan. (2008). Metodologi Penelitian Sosial. Penerbit PT Bumi Aksara : Jakarta.

[15] Rahmat, P. S. (2009). Penelitian Kualitatif. EQUILIBRIUM, 5, 1-8.

[16] Sani, K., Winarno, W. W., Fauziati, S., \& Handayaningsih, S. (2015). Pembuatan Enterprise Architecture Planning Dinas Kebudayaan Provinsi DIY Dengan Menggunakan Kerangka Zachman. Seminar Nasional Teknologi Informasi Dan Multimedia, 6-8.

[17] Sulaiman, A. (2015). Peraturan Menteri Pertanian Republik Indonesia Nomor 19/Permentan/HK.140/4/2015. 